\title{
Measurement and Assessment of Business Income and Performance in the Era of Creative Accounting Practice
}

\author{
Mr.Omada, Vitus Ikechukwu \\ Department of Accounting, Federal University Oye-Ekiti, Ekiti State, Nigeria
}

\begin{abstract}
Aggressive accounting, income smoothing, earning management and creative accounting are the financial reporting gimmicks that have influence on the differences in the approaches adopted by accounting practitioners in reporting business income and thereby influencing reported income. The difference accounting policies and approaches adopted by preparers of financial statements create differences in the measurement and assessment of business income through provision and loopholes in International Financial Reporting Standards (IFRSs) that lead to manipulation of financial numbers usually within the letter of the law and accounting Standards. Creative accounting practices employed by preparers of financial statements have created gap in the measurement and assessment of business income and performance due to the selfish interest of few stakeholders to the detriment of the larger society. principles-based accounting is the best in providing relevant, reliable and comparable financial information across reporting period and entities but it is to be recognized that to make principles-based approach more effective and efficient, some grey areas must be modified to avoid the risk of exposing financial information to manipulation through unethical behaviours. Cash flow is more reliable to access and measure entities performance because it is more difficult to manipulate than statement of financial performance and financial position.
\end{abstract}

Keywords: Creative accounting; Income measurement; International Financial Reporting Standards (IFRSs); Rules-based accounting; Financial Statement; Principles-based accounting.

DOI: $10.7176 /$ RJFA/10-18-11

Publication date:September $30^{\text {th }} 2019$

\section{Introduction}

Business growth in a developing economy is largely depending on the extent of the deployment and utilization of their resources human, capital and otherwise in order to maximise profit of the firm. Profit is a financial benefit that is realized when the amount of revenue gained from a business activity exceeds the expenses, cost, and taxes needed to sustain the activity. Any profit that is gained goes to the business's owner, who may or may not decide to spend it on the business. Profit is the revenue remaining after all costs are paid (Kimberly, 2019). Aggressive accounting, income smoothing, earning management and creative accounting are the financial reporting gimmicks used to moderate company's financial reports to encourage investors to buy the company's stocks to increase the firm's market value (Mulford and Comisky, 2002). Company accounts are subjected to detailed regulations of the Companies and Allied Matters Act 1990 and other specialized Acts. In addition, statements of accounting standards both local and international are equally issued to monitor the preparation of company accounts (Ofegbu, 2003). This implies that compliance with the laws is required as well as observance of the standards which help in streamlining differences in the preparation and presentation of the company accounts. The Act provides guidelines for keeping of accounting records and preparation of financial statements. For instance section 331(1) provides that every company should keep sufficient accounting records that will show and explain transactions of the company. The records will be such that will be able to disclose with reasonable accuracy the financial position of the company at any time. They shall be such that will enable the directors to be able to prepare financial statements that will comply with the requirements of Companies Act as to the form and content of the company's financial statements. This means that in keeping financial records of transactions, the provisions of the decree must be borne in mind so as to do that within the stipulations of the law. Financial statements are the end products of all financial transactions and records of the financial company, at the end of every financial period, the shareholders, creditors, debenture holders, investors, the government or its agencies, the employees, the management, other interest groups and the public at large look forward to seeing a summary result of operations of the company in order to satisfy their different desires generated by their various interests in the company. The directors have the responsibility of presenting to the shareholders, the result of the operational performance during the financial year; although as a management group they are required to do that. Section 334(1) of CAMA, 1990, states that it is the duty of the directors of the company to prepare annual accounts at the end of each financial year of the existence of the company. Preparations of these financial s are statement $r$ Accounting regulated by various Acts and Standards.

The Nigeria economy is one of such developing economies grappling with a lot of economic and social problems, among others inclusive in the myriad of problems are inflation of assorted types (cost push, Demand pull, et al), poverty of several dimensions confronting a large majority of their populations, insecurity due to the activities of armed robbers and the like, under-developed agricultural system, low level of technological 
development, dwindling manufacturing activity, general low standard of living et al (Onwumere, 2005). As the country forges ahead in its developmental efforts, the enterprises within its whether manufacturing, agricultural, distribution, service-oriented or otherwise must play vital role in preparation and presentation of income statement and financial position that show true and fair view of enterprises in other not to mislead interested stakeholders. There are different approaches used by accounting practitioners to derive accounting income of different forms of business organizations namely, sole proprietorship, partnerships, and incorporated forms of businesses.

However, most literature reviewed focused on the tax laws, the relevant and professional accounting organizations as the major influence of financial reporting of business enterprises in Nigeria and item influencing reported income. These studies have failed to consider income volatility risk as one of the major variables in determining factors that influence financial reporting of business enterprises. The primary objective of this study is therefore, to examine the impact of creative accounting practice on business income and the effect of income volatility on financial reporting of business enterprises.

\section{Theoretical Framework}

The determination and measurement of business income are primarily guided by statute. However, the determination and derivation of business income are fundamentally underline by theoretical accounting principles and concepts.

\section{Concept of Income}

Marquis (2017) contend that accounting income is distinct from cash flows; particularly money a business has in its coffers at the end of given period such as a month or fiscal year. Various regulatory guidelines highlight these distinctions, telling business how to record and report revenue and expenses data. These guidelines primarily come from the Financial Accounting Standard Board, the Nigeria Securities and Exchange Commission and the Institute of Chartered Accountants of Nigeria.

However, readers of financial statements should understand the approaches used by the accountant to produce the income amount. Income is the money that an individual, region/country earns in a year as a result of investing in a business (Okafor, 2009). Therefore, the measuring could be more appreciated by understanding the usefulness of business income than by merely interpreting and understanding the items that go into the computation of accounting income (Okafor, 2009). Accounting income can be defined as estimate of performance in the operations of a company (James, 2013). It is influenced by financing and investing decisions. Accounting income or loss generally recognizes realized gains and losses, and does not recognize unrealized gains and losses. For income to be realized it must be related to actual business transactions; in effect, the cash you have must increase or decrease. A change in market value rather than cash received is not an accounting income; it is an economic income or loss recognizes all gains and losses whether realized or unrealized.

Essentially, accounting income defined the ways companies evaluate their cash standing after the sale of an asset. This once again, differs from economic income in that economic income is the way for companies to account for changes in the value of a given asset in the market. The deciding factor is whether or not a transaction takes place.

According to Hendreksen (1977), industrialists regard any organization that produces income in excess of its total costs as profitable. Profit indicates some measure of efficiency in the application of human, financial and material resources. Any organization that wastes these resources is rarely profitable. According to Lewis et al, (1872), profits constitute the evidence that corporate operations have resulted in an increase in national wealth. Profitability in banking is closely associated with a bank's ability to stand up to creditors demand (Okafor, 1983) and in terms of granting of loans and advances (Wood and porters, 1979).

\section{Income Measurement}

Income measurement raises many conceptual and practical problems .For instance, the generally accepted accounting practices permit inconsistencies in the measurement of periodic income of different forms and even between different years for the same firm. For users of financial statements to understand the concept of business income, attempt should be made to understand and interpret transaction data that make up the entire records in the book of account (Okafor, 2009).

Accounting in any business establishment is perceived as a primary tool by which data relating to economic activities are measured, recorded and communicated to interested parties (Inaga, 1985). Communicating information on economic activities of a profit - oriented establishment implies reporting on its financial results. As commonly understood it is giving information on financial statements which includes statement of financial performance/profit and loss account and statement of financial position, and with respect to prevailing significant accounting. Such significant accounting policies may include basis of accounting, treatment of items involving foreign currencies, income recognition, treatment of property and equipment, revaluation of assets, depreciation of assets, stock valuation and others. 
The statement of financial performance/profit and loss account is a form of data presentation, showing the summation of many positive and negative items that go into the computation (Okafor, 2009). Data so derived is from the economic environment which is influenced greatly by suppliers, customers, credit institutions, government, shareholders and the social, political, and cultural environment where the business is located. Financial reporting is the provision of financial information about an entity to external users that is useful to them in making economic decision and for assessing the effectiveness of the entity. Financial reporting is of two types namely; management reporting and corporate reporting. Corporate reporting refers to audited accounts which are published externally as distinct from management reporting which is designed for internal use to manage the business. In corporate reporting, it is mandatory on even publicly quoted firm to comply with the regulatory framework of reporting income statement/ statement of financial performance for the year ended with reference date. However, the popular reference date in Nigeria is December 31.

\section{Substance over Form}

Different businesses or industries require different accounting formats and peculiar treatments. The same applies to different types of organisations. Hence there are the Partnership Act of 1890; The Companies and Allied Matters Act of 1990 as amended to date, the Bank and other Financial Institutions Decree (BOFID) 1991 (as amended) regulating the business and accounting for partnership, Companies and Financial Institutions respectively (Ugwoke R.O, 2010). However, in keeping the accounts of these organisations, the accountant appreciates the peculiar nature of the respective business instead of just what the law dictates. Thus accounts of organisations are presented in accordance with the substance and financial reality and not necessarily or simply with the legal forms.

\section{Concept of True and Fair View}

According to Ofegbu 2003, for financial statements to show a true and fair view of profit and loss account and of the balance sheet, the following must been observed in their preparation.

a. The general accepted accounting practice (GAAP) as codified in IAS and SAS must be complied with in the preparation of the accounts.

b. A satisfactory reason must be given for any deviation from the accounting standard or a different accounting policy adopted while preparing the accounts.

c. There must be relevant, reliable and sufficient evidence that transactions contained in the financial records are complete, accurate and valid.

d. There is no material misstatement as a result of errors and frauds in the financial statements.

e. Relevant provisions of the Company and Allied Matters Act (CAMA) and other relevant regulations have been observed in preparation of the financial statements.

However, the concept of true and fair view of financial statement has been eroded due to the exploitation of loopholes in the accounting standards and other financial regulations. Following the law (regulations), the standards $\left(\right.$ IAS $_{\mathrm{S}}, \mathrm{IFRS}_{\mathrm{S}}$ ) and the recommended practice, and even with the results audited by external companies, the scope for creative accounting remains large.

\section{Corporate Governance}

The main driving forces for Corporate governance code or corporate governance code development are; increase internationalization and globalization leading to investors investing outside their home countries; the differential treatment of foreign and domestic investors in terms of reporting right and dividend, excessive dominance of majority shareholders in insider jurisdiction caused many investors to call for parity of treatment; issue concerning financial reporting were raised by many investors and were the focus of much debate and legislations. Shareholders confidence in what was been reporting was eroded; natural difference among individual countries and increasing numbers of high profile corporate scandals and collapses including Polly Peck international, BCCI and Maxwell communication corporation prompted the development of corporate governance code in the earlier 90s. However, other scandals since then have raised questions about further measures that may be necessary. To combat the above problems, code of best practices was developed in many jurisdictions. The development of codes has been prompted by the need to clarify ambiguities in law or require a high standard of behaviour local legislation requires. Corporate governance codes have been developed to ensure local law complies with international best practices. The main objectives of corporate governance were as follows; to ensure adherence to and satisfaction of strategic objectives of the organization; to convey and reinforce the requirement relating to governance in local status and listing rules; to assist companies in minimizing risks by ensuring appropriate systems of financial control for monitoring risks and ensuring compliance with the law are in place; promote ethical behaviour with integrity; to restore(underpin) investors' confidence; to fulfil responsibilities to all stakeholders and to minimize conflict of interest between owners, managers and other stakeholders; to give both managers and owners balanced picture of what is happening in the organization through providing accurate and timely report of financial and operational data etc. Rule-based accounting is basically is list of detailed rules that must be followed when preparing financial 
statements. Many accountants favour the prospect of using rule-based standard because, in the absence of rules, they could be brought to court if their judgements of the financial statements were incorrect. The General Accepted Accounting Principles (GAAP) system is a rule-based accounting method used in the United States. Companies and their accountants must compile their financial statements in accordance with the rule which allows investors an easy way to compare the financial information of different companies. The 10 principle of the rule-based GAAP accounting system are; Regularity, Consistency, Sincerity with an accurate representation of the company's financial situation; Performance of methods; No expectation of compensation; prudence with no semblance of speculation; continuity; Dividing entries across in all financial reporting periods of time; Full disclosure in all financial reporting and good faith and honesty in all transactions. Principles-based accounting seems to be the most popular accounting method around the globe. Most countries opt for a principles-based system, as it is often better to adjust accounting principles to a company's transactions rather than adjustment a company's operations to accounting rules. The international financial reporting standards (IFRS) system- the most common international accounting standard- is not a rules-based system. The IFRS states that a company's financial statements must be understandable, readable, comparable, and relevant to current financial transactions. Principles-based approach of accounting encourages the use of financial arranging of information in order to achieve the preferred accounting results without paying attention to specific rules. This however, resulted in poor financial reporting. As a result of such detailed and comprehensive rules, it gave a window of opportunity for preparers of financial statements to easily manipulate and restructure financial information for the organizations' benefit without consideration of the specific rules and guidelines. Based on Grant Thornton (2008) Definition, it states that an 'appropriate principlesbased approach must be broad in its scope'. This standard requires a clear hierarchy of primary concepts with limited guidance. The additional guidance provided should be limited to a concise explanation that is built into the standard itself as well as having a small number of interpretations on key issues which cannot be comprehended (ICAS, 2006b). Principles-based approach seems to be the way forward as the new form of reporting financial information (statements). It also addresses the concern of that the supporters of rules-based face in accounting standards such as rules-based having too many bright lines and no or less room for judgement (ICAS, 2006). The main problem overall is that there is no one set accounting method that has been universally adopted. There are currently more than 110 countries that use IFRS as their accounting standards, while the U.S. uses the rules-based GAAP method. That means investments, acquisitions, and mergers may require a different lens when comparing international competitors such as Exxon and BP, which us different accounting methods. Critics of principlesbased accounting systems say they can give companies far too much freedom and do not prescribe transparency. They believe because companies do not have to follow specific rules that have been set out; their reporting may provide an inaccurate picture of its financial health. In the case of rules-based methods like GAAP, complex rules can cause unnecessary complications in the preparation of financial statements. And having strict rules means that accountant may try to make their companies more profitable that they actually are because of the responsibility to their shareholders. That was the case for Enron and WorldCom. In 2001, Enron shareholders lost almost $\$ 75$ billion in value after the company kept its major debts off its balance sheets. The company ended up filing for bankruptcy. An internal audit found billions of dollars in fraud at WorldCom in 2002, where assets were inflated by much as $\$ 11$ billion alongside fake accounting entries and inflated revenue. Andrews (2002) and Hofheinz (2002) both emphasised that supporters of IAS believe that the lack of guidance from the principles-based approach makes organisations and audit firms more restrained and as a result, the need for misuse of the system is reduced. Based on ICAS, (2006) illustration of principles, they defined principles as a 'general statement with widespread of support which is intended to provide truth and fairness" in the utmost way possible. Moreover, some rules may be proposed to 'guide the adherence of principles' but at end of the day, it always results in making professional reasonable judgements. Shortridge and Myring (2004) literature highlighted the 2002 presentation which Robert Herz (Chairman of FASB) explained the concept of principles-based standards. He stated that under the principlesbased approach, the key objectives of a good reporting are laid out as the starting point. Almost every organisation is required to prepare financial statement which is set out by the either Financial Accounting Standard Board (FASB) or IFRS depending on the Standard that is adopted in that country (Investopedia, 2012). Although with the approaching global convergence of IFRS in countries, organizations are expected to report financial information based on IFRS standards. According to the Principles versus Rules Working Group set up by the ICAS 2006, it states that only the principles-based approach to accounting can fully serve the needs of businesses and the public interest as a whole.

\section{Creative Accounting}

The accounting process consists of dealing with many matters of judgement and of resolving conflicts between competing approaches to the presentation of the financial events and transactions............this flexibility provides opportunities for manipulation, deceit and misrepresentation (Michael Jameson, 1988). Creating accounting constitutes the instrument for fraudulent financial reporting that entails intentional misstatement by corporate management of financial result in order to mislead investors and other users of financial reports is considered as 
universal phenomenon (Akhidime et al, 2014). The shareholders and market reaction is related and more to managers' actions and directors are increasingly judged on profit, growth and Earnings per share (EPS) and have large bonuses at stake. So companies (and directors) want to use the report to present the message they want investors to see, and at times this needs to creative accounting. These creative accounting practices in financial reporting have been termed as "'the art of faking the balance sheet'" (Bertolus). "'the art of calculating the balance sheet" (Lignon). The manipulation of financial information depends on manipulative behaviours. One is " macro manipulation" and the other one is "'micro manipulation'. Macro manipulation is when the policy makers come to know that the changes which are about to be made will not be favourable to them they start lobbying against it. They are convincing their companions to reject the rules. In micro manipulation, the preparers try to hide the true results in order to keep the stakeholders away from the truth and show them the wrong picture on individual level (Gowthorpe and Amat, 2005). Creative accounting is neither illegal nor legal only the maximum use of it pushes companies in scandals (Fizza, T and Qaisar, A.M, 2015). Creative accounting plays significant role in financial reporting but has been negatively correlated that means more managers involved in it may decrease the value of financial information (Fizza, T and Qaisar, A.M, 2015)

\section{Prevention of Creative Accounting}

Those companies most at risk for fraudulent financial reporting tend to be those that have one or more of the following: weak internal control; no audit committee; a family relationship among directors and/or officers; and /or a board of directors dominated by individuals with significant equity ownership and little experience serving as directors of the companies. To prevent creative accounting, the experts opine that accountants and managers should be dividing the duties of an internal control checklist.

Furthermore, an independent audit committee should always have someone with a strong accounting background and audit experience who deals directly with outside auditors. The investors should diversify their investment portfolio to circumvent the problem related to the creative accounting by few unscrupulous companies. Companies have to adhere strictly to the ethical values with the long-run and short-run of the life of the company. The accounting and accounting practices have to be consistent and show to investors that it is following the ethical practices in all its financial dealing as well as reporting. According to Mulford (2002), the expert in the field; the most common creative accounting practices include improper revenue recognition and misreporting expenses. Creating accounting has long been a long practice among companies in Nigeria, traces the motives behind the practice to selfish interest of few stakeholders to the detriment of the common good of the larger society (Akhinime et al, 2014). Measures for the curtailment of the practice are found to lie in the collaborative efforts of the professional accounting bodies, accounting training institutions, the government and the judiciary (Akhidme et al, 2014).

\section{Items Influencing Reported Income}

The determination of profit/income is often complicated because of the interplay of depreciation, the diversity of revaluation procedures, different stock valuation methods and the tax provisions (Okafor, 2009). Depreciation is deducted from gross profit before arriving at the profit before interest and tax, but the method of calculating depreciation of assets varies from firm to firm because some firms use the straight line method, while others prefer the reducing balance method or other methods; choice of method is usually influenced by the motive of the result influence in the financial report. Certainly different methods of depreciation yield different expenditure figures which ultimately produce different figures of profit after interest and tax. In addition, there are factors that affect the calculation and apportionment of annual depreciation. Examples of such factors are the cost of the asset which is known and the useful life of the asset as well as the residual value of the asset which are matters of estimation (In real life situations, estimates of depreciation charges are rarely exact (Okafor, 2009).

Revenue generated from asset revaluation in the form of capital gain is sometimes included in profits and yet, firms differ substantially in their approach to the revaluation of asset. Revenue can be recognized on sales basis, on cash basis or on a percentage of completion of contract basis (Hendriksen, 1977). Difference arising from these different income recognition methods could therefore, result in differences in the amount of accounting income reported. Different inventory valuation methods- such as FIFO, LIFO, and Weighted Average Method- can affect your bottom line in different ways, so it's important to choose the right method for your business. According to the First-in-first-out (FIFO) inventory valuation method, its assume that inventory items are sold in the order in which they are manufactured or purchased. In other words, the oldest inventory items are sold first. The FIFO method is widely used because companies typically sell products in the order in which they are produced, so it best represents the actual flow of goods in a business. On the contrary, Bastable and Meriwether (1975) in their article "FIFO in an inflationary Environment' demonstrated how FIFO overstates accounting income during periods of high inflation when compared with the use of current replacement cost. With the Weighted Average inventory valuation method, inventory and Cost of goods sold (COGS) are based on average cost of all items purchased during a period. This method is usually used when a business doesn't have much variation in its 
inventory. The last-in-first-out (LIFO) inventory valuation method assumes that the most recent purchased or manufactured items are sold first. When the prices of goods increase, cost of goods in the LIFO method is relatively higher and ending inventory balance is relatively lower. Difference stock valuation approaches produce difference results for cost of sales and consequently different profit results. For instance the Last in First out (LIFO) method reflect historical price which make the method completely meaningless for the evaluation of current performance. Another area of creative accounting practice by directors in the preparation of financial statement is recognition of finance lease as operating lease. The approach of IAS 17 was to distinguish between two types of lease. Leases that transfer substantially all the risks and rewards of ownership of an asset were classified as finance leases. All other leases were classified as operating leases. The classification set out in IAS 17 was subjective and there was a clear incentive for the preparers of lease's financial statements to 'argue' that leases should be classified as operating rather than finance lease in order to enable leased assets and liabilities to be left out of the financial statements. It was for this reason that IFRS 16 was introduced. IFRS 16 defines a lease as 'A contract, or part of a contract, that conveys the right to use an assets for a period of time in exchange for consideration'. In order for such a contract to exist the user of the assets needs to have the right to: (a) Obtain substantially all of the economic benefits from the use of the assets. (b) The right to direct the use of the asset.

\section{Institutional Influences}

Companies keep proper books of accounts in accordance with generally accepted accounting principles. Similarly, financial statements are prepared in conformity with procedures and formats prescribed by relevant statutes. Accounting income measured is taxed according to the tax provisions, while the professional accounting bodies are legally authorized to prescribe methods for handling accounting matters of business establishment (Okafor, 2009). The Companies and Allied Matters Act 1990 (CAMA) as amended is the principle legislation that regulates the operation of Nigerian companies. The accounts so prepared by companies are in the manner so required and in compliance with the Statements of Accounting Standards issued by the Nigerian Accounting Standards Board. The law regulating the taxation of profits of companies operating in Nigeria (excluding those involved in upstream petroleum activities) is the Company Income Tax Act (CITA) as amended by the Financial (Miscellaneous Provisions) Act Cap. 354, LFN 1990 as amended is the tax law under which companies engaged in upstream sector of the petroleum industry are assessed for tax purposes (Okafor, 2009). Oil companies operating in the downstream sector are assessed tax under the CITA cap. 60 LFN 1990 (SAS 19 paragraph 7). However, oil companies whose activities involve marketing of petroleum products or refined oils are not taxed under PPT but not CITA. Tax liability is calculated on chargeable profit. The federal Inland Revenue Service (FIRS) officially identified as the Federal Board of Inland Revenue (FBIR) administers the taxation of companies in Nigeria. The Board is responsible to the Federal Ministry of Finance, which superintends over company tax, among other things, on behalf of the Federal Government. The tax year runs from $1^{\text {st }}$ January to $31^{\text {st }}$ December the same year and the tax is collected on preceding year basis (PYB). Profit can only be taxed on actual year basis when the commencement, cessation or changes of accounting period provisions are being applied.

According to Aspen institute, Volatility is about change and unpredictability. Knowing a volatile person means not knowing well what he or she will do next. Volatility in financial parlance usually refers to how much an asset's value fluctuates from its general trend; high volatility equals greater uncertainty about what the value will be tomorrow or next month or next year. Looking at firm's financial statements. An income and expense report would track what is coming in from earnings and benefit payments (and perhaps interest or other returns on investment) and what is going out in expenditures for today and payments on long-term obligations (perhaps a mortgage or student loans). There would also be a balance sheet of what is owned and what is owed. When those hypothetical financial statements are in flux - especially when the changes are unwanted, frequent, or unpredictable - the firm finds itself on shaky economic footing. It experiences volatility. In the context of business finances, volatility is usually defined as the variance of income, meaning the amount of divergence from the average. It can also be measured by the number of substantial spikes and dips in income over time.

\section{Conclusion}

The differences accounting policies, approaches and procedures adopted by accounting practitioners and preparer of financial statements in the measurement and reportage of business income create wide differences in the measurement, assessment and interpretation of business income through provision and loopholes in International Financial Reporting Standards (IFRSs) that gave opportunity for both macro and micro manipulation of financial information usually within the letter of the law and accounting Standards. Creative accounting practice employed by preparers of financial statements has created wide gap in the measurement and assessment of business income and performance due to the selfish interest of few stakeholders to the detriment of the larger society. A company is involved in frauds or scandals because of several factors like unethical behaviours, agency problem and nonprofessional attitude. Unethical behaviour is a cause of lack of moral values which might be individual as well as professional. However, there is no doubt that principles-based accounting is the best in providing relevant, reliable 
and comparable financial information across reporting period and entities but it is to be recognized that to make principles-based approach more effective and efficient, some grey areas must be modified to avoid the risk of exposing financial information to manipulation through unethical behaviours and ensure that the credibility of financial information is not eroded.

\section{Recommendations}

However, there is no doubt that principles-based accounting is the best in providing relevant, reliable and comparable financial information across reporting period and entities but it is to be recognized that to make principles-based approach more effective and efficient, some grey areas must be modified to avoid the risk of exposing financial information to manipulation through unethical behaviours and ensure that the credibility of financial information is not eroded.

1. The need for collaborative effort among the professional accounting bodies, accounting training institutes, the government and the judiciary in the fight to curtail creative accounting practice among preparers of financial statements to save potential and prospective investors.

2. There is need for urgent review of some accounting standards that are exposed to loopholes which guarantee access to international misstatement by corporate management of financial results in order to mislead investors and other users of published financial report.

3. Cash flow should be used to access and measure entities performance because it is more reliable and more difficult to manipulate than statement of financial performance (profit or loss).

4. Audit committee should be liable for material misstatement in order not erode investors' confidence.

\section{References}

Adepoju, A. (2002). "Capital Investment Appraisal Techniques: The way forward”. ICAN Student Journal Vol. 7 No. 12.

Akhidime, Augustine E hijeagbon, and Okafor Chinwuba. A (2011). 'Creative Accounting in Nigeria: An Empirical Analysis" Nigeria Journal of Finance and Management.

Bastable, C.W. and Jacob D. Meriwether ''FIFO in an Inflationary Environment' Journal of Accounting, March.

Eze, J. C. (2001). Principles and Techniques of Management Accounting. Enugu: J.T.C Publishers

Ezejulue, A.C (2001). Premier on International Accounting. Port Harcourt, Educational Books and Investments Ltd.

Fizza, T and Qaisar A.M. (2015).'Creative Accounting and Financial Reporting: Model Development and Empirical Testing', International Journal of Economics and Financial Issues, 5(2),

Hendriksen, Eldon S. (1977). Accounting Theory. Third Ed., Illinois Richard D. Irwin, INC.

Inanga, E.L (1985). Principles of Accounting Hernemann Nigeria Ltd. Ibadan

Kimberly Amadeo (2019). Profit the catalyst for Capitalism. www.thebalance.com.

Largay, J. (2002). Lesson from enron. Accounting Horizon, 16(2), 154

Marquis Codja (2017). Accounting vs Cash flow. www.smallbusiness.chron.com

Mulford, C.W. and Comisky, E.E. (2002). The Financial Numbers Game, Detecting Creative Accounting Practices. Canada: John Wiley \& Sons. Inc.

Ofegbu, G.N. (2003). Advanced Financial Accounting. Enugu: Precious Publishers Ltd.

Okafor, R.G (2009). "Institutional Imperatives on the Measurement of Business Income in Nigeria" Nigeria Journal of Management Research, June.

Okafor, R.G (2008). 'Analysis of preference of Organizational Forms for Small Scale Investors in Nigeria: Issue of Income Tax Consideration"' Journal of Accounting of National Accountants of Nigeria.

Okafor, G.O. (2006). 'The ethics of accountancy profession', Journal of Global Accounting, 2 (1).

Onwumere, J.U.J. (2009). Business and Economic Research Methods. Enugu: Vougasen Ltd.

Sidney, Davidson (1973). 'the Meaning of Business Income: an International Comparison' Selected

Paper No. 24 presented at the Executive Program Club Luncheon talk at the Pick-Congress Hotel, Chicago, November.

Staubus, G.J. (1986). '’Testing Inventory Accounting'’ Accounting Review July.

Steve, Lawrence (1996). International Accounting, London International Thomson Business Press (ITB)

Ugwoke, R.O (2010). Financial Accounting: A Theoretical and Problem Solving Approach. Enugu: John Jacob's Classic Publishers Ltd.

www.aspeninstitute.org

Ziliak, James, Brandley Hardy, and Christopher Bollinger (2011).'Earning Volatility in America: Evidence from Matched CPS labour Economics", 